inOfedia $\quad \begin{aligned} & \text { InMedia } \\ & \text { The French Journal of Media Studies }\end{aligned}$

$4 \mid 2013$

Exploring War Memories in American Documentaries

\title{
From Film Archives to Digital Filmmaking: Exploring War Memories in American Documentaries
}

Georges Fournier and Delphine Letort

\section{(2) OpenEdition \\ Journals}

Electronic version

URL: http://journals.openedition.org/inmedia/702

DOI: 10.4000/inmedia.702

ISSN: 2259-4728

Publisher

Center for Research on the English-Speaking World (CREW)

\section{Electronic reference}

Georges Fournier and Delphine Letort, «From Film Archives to Digital Filmmaking:

Exploring War Memories in American Documentaries », InMedia [Online], 4 | 2013, Online since 15

November 2013, connection on 08 September 2020. URL : http://journals.openedition.org/inmedia/ 702 ; DOI : https://doi.org/10.4000/inmedia.702

This text was automatically generated on 8 September 2020.

(c) InMedia 


\title{
From Film Archives to Digital Filmmaking: Exploring War Memories in American Documentaries
}

\author{
Georges Fournier and Delphine Letort
}

\section{EDITOR'S NOTE}

This dossier was followed for InMedia by Cecilia Tirtaine and Thibaut Clément.

1 The memory of American wars has been largely influenced by iconic visuals, used either to promote patriotic cohesion behind the rationale for war or to question the motivations behind the United States military involvement abroad. ${ }^{1}$ War documentaries, while serving conflicting perspectives in times of war, participate in the construction of sites of memory while retrospectively engaging with war issues. ${ }^{2}$ Incorporating archive footage as a source of historical knowledge, these nonfiction films produce 'modern memory' which, according to Pierre Nora, 'relies entirely on the materiality of the trace, the immediacy of the recording, the visibility of the image.' Based on first-hand interviews and witness statements that convey the authenticity the genre strives for, war documentaries aim to bring to light the untold stories of the war, shaping private, repressed, or confessed memories into shared, public collective memory. ${ }^{4}$ This construction of collective memory has increasingly become a selfconscious endeavor given the soldiers who now provide visual records of war with their digital cameras.

2 Drawing on personal and public archives, war documentaries can hardly reconcile the dual perspective that underlies the framing of war. In his discussion of the Vietnam War, Milton J. Bates pits the perceptions of the man on the battlefield against the 
knowledge of the military command to shed light on the gap of knowledge between the two:

The man on the hilltop, whether he is an elected political leader or one of those civilian or military technocrats whom Noam Chomsky called the 'new Mandarins,' knows better than the man in the valley because he knows so much more and knows it dispassionately. ${ }^{5}$

3 From the soldiers' accounts to the version formulated by government officials, documentaries highlight the distance that separates the ordinary grunt from the control room. Whether they are based on media archive footage or on witnesses' visual and oral accounts, documentaries craft a history of war that often obscures rather than clarifies the nature of experience amidst the fog of war.

Political philosopher Michael Walzer contends that 'hypocrisy is rife in wartime discourse, ${ }^{\prime 6}$ highlighting the layers of deception, and even self-deception, that weigh on war narratives. Not only do lies and truth mingle in the official reports that attempt to manipulate public opinion in favour of a pro-war stance, but they also merge in the memories of veterans whose combat experiences may not be accurate. It is in this sense that military historian Roger J. Spiller metaphorically calls combat history's 'darkest corner': an allusion to the confusion that shrouds battle on the front. ${ }^{7}$

In this issue of InMedia, contributors were prompted to investigate the recent evolutions of war documentary, while keeping in mind the impact of digital technologies and the growth of corporate media. The authors of the collected articles emphasize the link between war documentary filmmaking and the shaping of collective memory, which has become a self-conscious effort on the parts of producers and directors. Clearly, war documentaries have become important cultural commodities, which Debra Ramsay demonstrates by analysing the marketing strategies behind Band of Brothers (2001) and The Pacific (2010), two docudrama miniseries that endorse a nostalgic discourse while contributing to shaping the memory of World War II through re-enacted combat scenes. Filmmakers Steven Spielberg and Tom Hanks evoke the powerful impact of the battles as interviewed veterans remember them in spectacular scenes, while simultaneously illustrating the influence of commercial television on documentary filmmaking. Promoted as authentic documents through the 'look of period combat footage,' the series nonetheless convey an American perspective that the author defines through a close examination of all paratextual materials. Ramsay underscores the connection between the series and the construction of collective memory, using the commemoration of the war to reinforce the myth of the 'good war' which World War II has come to epitomize in collective memory.

6 Although many fiction films exist about the role of memory in the Vietnam War, few documentaries have taken up this subject. This absence is particularly concerning because testimonies can proffer stunning revelations concerning the aftermath of conflict, such as repressed memories of traumatized veterans, post-war erasures, and other distortions in both official and popular memory. Little attention has been given to the way nations deal with the memories of war crimes, and this is particularly true for the USA and the Vietnam War. Daniel Grinberg addresses these issues in his study of Winter Soldier, a 1972 collaborative documentary. The film spans three days during which Vietnam veterans, gathered in Detroit, recount the atrocities committed there and the falsifications designed to hide crimes. In "Depictions of Memory in Winter Soldier as Indicator of Cultural Memory," Daniel Grinberg aptly shows the processes of 
erasure found within both official and collective memory. His study of the confrontation between personal and official discourses serves to highlight the entanglements and the difficulty of a nation coming to terms with this trauma. Deductive in its approach, Grinberg's work delves into the delicate connections and interactions between public history and personal testimony; it explores how nations come to terms with their memory.

7 As this year marks the tenth anniversary of the beginning of the war in Iraq, several articles in this issue aim to assess the impact of digital technologies on documentary filmmaking. Barry Mauer explores the relationships between the media and the political and military spheres in the early days of the Iraq war through a study of Jehane Noujaim's Control Room (2004). The complexity of war images broadcast on TV channels beseeches us to keep in mind national and international interests, whether private or institutional. The author makes a case for increased fairness and calls for the mediascape to represent war differently in order to avoid cliché images, which have become ubiquitous in news and current affairs. Mauer pursues the staging complicit in all representation and advocates a dramatic approach that would take into account theories related to rhetoric. In the second part of this essay, the author ponders over the role of journalists as independent reporters or agents of propaganda. Through a detailed analysis of The War Tapes (Deborah Scranton, 2006), which incorporates a selection of footage filmed by American military men deployed on the ground, Delphine Letort interrogates the power of digital cameras in shaping the perception of the Iraq war. Gaining authenticity from its home movie aesthetics, The War Tapes captures the soldiers' intimate war experiences, shedding light on traumatic events whose haunting power lasts long after the men return to their homeland. In particular, Scranton's re-purposing of the original stock footage subdues the soldiers' critical voices, deflecting attention from the war itself to the soldiers' suffering. The produced film thus highlights the role of embedded digital cameras and the blurring line between private and public memories. ${ }^{8}$

9 Calvin Fagan underlines that the cinéma vérite mode, adopted in most documentaries made on the Iraq war, fails to grasp the complexities of the new technological context in which the military operate. Fagan posits that the hybridity between fiction and nonfiction is a result of documentary filmmaking's adaptation to war's digital mediation. Full Battle Rattle (Tony Gerber/Jesse Moss, 2008) and Serious Games (Harun Farocki, 2009-2010) are reflexive works that question the use of digital media in the training of the military. These documentaries highlight the developments of new technologies and show their contribution to the virtualisation of war, which primarily affects the soldiers' relationship with the enemy. Collective memory is undoubtedly conditioned by the ways in which recent conflicts are represented and captured.

The present contributions offer insight into the representations of war that claim to be testimonial, whether they are personal testimonies or pro-filmic elements easily accessible through modern technological tools or re-enactments. At a time when the United States has had to reassess its military role, reconsider its interventions, and face new forms of warfare, there arises a need to revisit questions about the representation of war and how memories of past wars affect policy-making, debates to which the present issue contributes. 


\section{BIBLIOGRAPHY}

Bates, Milton J. The Wars We Took to Vietnam: Cultural Conflict and Storytelling. Berkeley and Los Angeles: University of California Press, 1996.

Barnouw, Eric. Documentary: A History of Non-Fiction Film. New York and Oxford: Oxford University Press, 1993 [1974].

Chapman, Jane. Issues in Contemporary Documentary. Cambridge UK \& Malden USA: Polity Press, 2009.

Ferro, Marc. Cinema and History. Translated by Naomi Greene. Detroit: Wayne State University Press, 1988.

Fussel, Paul. The Bloody Game: An Anthology of Modern War. London: Scribner's, 1991.

Hariman, Robert and John Louis Lucaites. No Caption Needed. Chicago: The University of Chicago Press, 2007.

Hoskins, Andrew and Ben O'Loughlin. War and Media, the Emergence of Diffused War. Cambridge \& Malden: Polity Press, 2010.

McBride, Joseph. Frank Capra: The Catastrophe of Success. Jackson: The University Press of Mississippi, 2011.

Nora, Pierre. "Between Memory and History: Les Lieux de Mémoire." Representations, No. 26, Special Issue: Memory and Counter-Memory, (Spring, 1989): 7-24.

http://www.history.ucsb.edu/faculty/marcuse/classes/201/articles/

89NoraLieuxIntroRepresentations.pdf. Accessed September 9, 2013.

Nichols, Bill. Introduction to Documentary. Bloomington, Indiana: Indiana University Press, 2010 [2001].

Nichols, Bill. "The Voice of Documentary." In New Challenges for Documentary, edited by Alan Rosenthal and John Corner, 17-34. New York \& Manchester: University Press, 2005 [1985].

Walzer, Michael. Just and Unjust Wars: A Moral Argument with Historical Illustrations. New York: Basic Books, 1977.

\section{NOTES}

1. Robert Hariman and John Louis Lucaites, No Caption Needed (Chicago: The University of Chicago Press, 2007).

2. "Lieux de mémoire originate with the sense that there is no spontaneous memory, that we must deliberately create archives, maintain anniversaries, organize celebrations, pronounce eulogies, and notarize bills because such activities no longer occur naturally." Pierre Nora, "Between Memory and History: Les Lieux de Mémoire," Representations, No. 26, Special Issue: Memory and Counter-Memory, (Spring, 1989), 12.

<http://www.history.ucsb.edu/faculty/marcuse/classes/201/articles/ 89NoraLieuxIntroRepresentations.pdf>, accessed on September 9, 2013.

3. Nora, "Between Memory and History: Les Lieux de Mémoire," 13.

4. Nichols Bill, Introduction to Documentary (2001; Bloomington, Indiana: Indiana University Press, 2010), xiii. 
5. Milton J. Bates, The Wars We Took to Vietnam: Cultural Conflict and Storytelling (Berkeley \& Los Angeles: University of California Press, 1996), 220.

6. Michael Walzer, Just and Unjust Wars: A Moral Argument with Historical Illustrations (New York: Basic Books, 1977), 20.

7. Roger J. Spiller cited in Paul Fussel (ed.), The Bloody Game: An Anthology of Modern War (London: Scribner's, 1991), 313.

8. Andrew Hoskins and Ben O'Loughlin, War and Media, the Emergence of Diffused War (Cambridge \& Malden: Polity Press, 2010), 22-23.

\section{AUTHORS}

\section{GEORGES FOURNIER}

Georges Fournier is Senior Lecturer in English Civilisation at the Department of Foreign Languages of the Jean Moulin University of Lyon. His main research interest lies in British authored television. He has published many articles on political docudrama and is currently conducting research in factual programming.

\section{DELPHINE LETORT}

Delphine Letort is Senior Lecturer in the English Department at the University of Le Mans (France) where she teaches American civilisation and film studies. Her research explores the relationship between history, memory, and film in American fiction and nonfiction cinemaincluding war documentaries and African American television films. She studies the ideological construction of stereotypes and the politics of representation developed in Hollywood productions. 